\title{
Sensory and Physicochemical Characteristics of Manyung (Arius thalassinus) Kekian High Fiber with the Addition of Eucheuma cottonii Seaweed
}

\author{
Meisya Asri Widiyanti, Lukita Purnamayati* and Romadhon \\ Department of Fish Product Technology, Faculty of Fisheries and Marine Science, \\ Universitas Diponegoro, Semarang, Indonesia \\ *Corresponding author: lukita.purnamayati@live.undip.ac.id
}

\begin{abstract}
Kekian is made by mixing minced fish meat with seasoning, fillers and binders; then shaped and wrapped with tofu skin. Kekian has a low dietary fiber, so the addition of seaweed puree is expected to increase the dietary fiber in kekian. The purpose of this study was to determine the effect of the addition of different seaweed puree concentrations (Eucheuma cottonii) to the characteristics of manyung (Arius thalassinus) kekian and determine the optimum concentration to deliver the best characteristics. The experiment was conducted in the laboratories with one factor in completely randomized design. The concentrations of the seaweed purees were as follow: $0 \%, 20 \%, 30 \%$ and $40 \%$ with three replications. The sensory data were analyzed using the Kruskal-Wallis test, while the dietary fiber, moisture, protein, Water Holding Capacity (WHC) and gel strength were analyzed using ANOVA. The results showed that the different seaweed puree concentrations significantly affected the sensory and physicochemical characteristics of kekian. The higher the concentration of E. cottonii in the kekian, the panelist acceptance, protein content and gel strength were lower. However, with higher concentration of seaweed puree, the dietary fiber, moisture content and WHC increased. The addition of $20 \%$ E. cottonii in the kekian yield in an acceptable product and high dietary fiber of $6.03 \%$.
\end{abstract}

Keywords: characteristic; dietary fiber; Eucheuma cottonii; kekian; manyung fish

Cite this as: Widiyanti, M. A., Purnamayati, L., \& Romadhon. (2021). Sensory and Physicochemical Characteristics of Manyung (Arius thalassinus) Kekian High Fiber with the Addition of Eucheuma cottonii Seaweed. Caraka Tani: Journal of Sustainable Agriculture, 36(1), 1-10. doi: http://dx.doi.org/10.20961/ carakatani.v36i1.41553

\section{INTRODUCTION}

Seaweed is a macroalgae which is widely used in food, cosmetics and pharmaceutical industries. Seaweed has been used as a raw material in bread, confectionery, drinks, snack, soup, condiments, noodles and pasta. In cosmetics, it has been applied as beauty enhancer on skincare products such as moisturizer, anti-aging cream and body scrub. Meanwhile, in pharmaceutical, it is useful as a nutritional supplement (Bouga and Combet, 2015; Pati et al., 2016; Pereira, 2018). Seaweed, especially Eucheuma sp., has been developed to meet industry needs (Priono, 2016). Utilization of seaweed is associated with its nutrient content that is rich in carbohydrates, proteins, fats and bioactive components (Nabti et al., 2016). Its nutrition content has also been used in agriculture and horticulture to increase crop productivity (Battacharyya et al., 2015; Hernández-Herrera et al., 2018).

Eucheuma sp. significantly contributes to the production of wet seaweed in Indonesia which reached 11.6 million tons. Indonesia is

\footnotetext{
* Received for publication May 9, 2020

Accepted after corrections September 11, 2020
} 
one of the significant producers of seaweed and contributes nearly $40 \%$ of total world seaweed production (around 30 million tons) (Wibowo, 2019). Eucheuma cottonii contains fiber which plays an essential role in human health. Dietary fiber is a food component that cannot be hydrolyzed by digestive enzymes and it is useful in slowing down the digestion rate of food in the intestine, giving a more prolonged feeling of fullness and it can delay the increase of blood glucose (Noviasari et al., 2017), prevent cardiovascular disease, obesity and cancer (Das et al., 2020). Seaweed is a more reliable source of soluble fiber compared to nuts, fruits and cereals which are generally only high in insoluble fiber. The content of water-soluble fibers such as agar, carrageenan and alginate in E. cottonii seaweed $(18.3 \%)$ is higher than insoluble fiber (6.8\%); while red beans contain $1.36 \mathrm{~g}$ soluble fiber and $5.77 \mathrm{~g}$ insoluble fiber (Istiqomah and Rustanti, 2015). E. cottonii contains $67.5 \%$ fiber, $39.47 \%$ waterinsoluble fiber and $26.03 \%$ water-soluble fiber (Satriani et al., 2018).

Although the benefits of dietary fiber are considerably great, the fiber consumption in Indonesia is only $10-14 \mathrm{~g}$ per day based on data of Recommended Dietary Allowances (RDA) (Khoirunisa et al., 2019). This value is lower than in China, which reaches $19 \mathrm{~g}$ per day. The recommended fiber consumption is $32 \mathrm{~g}$ per day according to RDA and $25 \mathrm{~g}$ per day based on the Food and Drug Administration (FDA). Therefore, the development of diversified seaweed-based high fiber food products is needed to increase dietary fiber intake ( $\mathrm{Li}$ and Komarek, 2017; Shanti et al., 2017; Septiana et al., 2018).

The seaweed addition could increase the fiber content and improve the physical characteristic of kekian. The Eucheuma sp. contains carrageenan, which works as a gelling agent (Nur Fatin Nazurah and Nur Hanani, 2017; Fontes-Candia et al., 2020). Some researchers have used Eucheuma to be developed into noodles (Halimah et al., 2016), pasta (Firdaus et al., 2017) and jelly candy (Ismawati et al., 2019). The application of Eucheuma sp. in fish-based products, however, is still limited. In this study, kekian, a fish-based product, was developed with the addition of Eucheuma sp.

Kekian is originally a Chinese food made from minced fish meat and mixed with seasoning, fillers and binders then shaped and wrapped with tofu skin (Mustafida et al., 2019). It can be served as steamed or fried and usually used as a complement to the main dish (Hadibroto, 2011). Kekian also can be made from chicken, shrimp or fish. Fish as a raw material which has many benefits, such as a source of animal protein, containing omega-3 fatty acids and fish meat is easily digested. Also, fish meat is accepted by all religions (Kaiang et al., 2016). Kekian is a fish jelly product and the texture is the most critical parameter in determining its quality (Wibowo et al., 2015). The limitation of fish as a raw material is its low fiber content. For example, red tuna meatball has $0.5 \%$ of dietary fiber per serving (Hermalena and Salihat, 2018), while fish roll contains $2.05 \mathrm{~g}$ $100 \mathrm{~g}^{-1}$ fiber (Kolade, 2015).

The addition of seaweed puree is expected to increase the gel strength and the dietary fiber. The addition of seaweed puree in low concentration produces a somewhat chewy texture, while the addition in high concentration produces a chewy texture due to excess water. An increase in the concentration of seaweed puree is followed by increase in fiber content. It shows the effect of seaweed substitution on fiber content (Handayani and Aminah, 2011). Therefore, in this study, we attempted to develop a high fiber-based manyung fish kekian. The purpose of this study was to determine the effect of the addition of seaweed puree and determine the best seaweed puree formula.

\section{MATERIALS AND METHOD}

\section{Materials}

Raw materials used in this study were manyung fish (Arius thalassinus) from Pati, Central Java, Indonesia, which average weight of $2 \mathrm{~kg}$ and a length of $45-50 \mathrm{~cm}$. The manyung fishes were then filleted (removal of skin and bones). E. cottonii was obtained from Karimunjawa, Central Java, Indonesia in dry condition and the other materials were obtained from the local market in Semarang, Central Java, Indonesia. The equipment used in for the production were meat grinder, digital scales, steaming pot, tray and cutting board.

\section{Seaweed puree}

The procedure for $E$. cottonii seaweed puree referred to Princestasari and Amalia (2015) and Febriana et al. (2017) with some modifications. 
First step was to wash the dried seaweed thoroughly and then soaked them in freshwater measured ten times the weight of the seaweed. The seaweed were soaked in a container for 1-2 days. Seaweed that has been soaked then cut and ground using a grinder for \pm 3 minutes to form seaweed puree.

\section{Kekian}

The making of kekian in this study referred to the Wibowo et al. (2015) with modifications. All of the ingredients: raw materials, additives and supplementary ingredients were mixed into a thick mixture. The additional ingredients, the seaweed purees were added according to the treatments, namely K0 (0\%), K20 (20\%), K30 $(30 \%)$ and $\mathrm{K} 40(40 \%)$. The mixed dough was then wrapped using tofu skin that had been cut square $10 \mathrm{~cm}$ in size and shaped like a tube with a length of $\pm 10 \mathrm{~cm}$. The kekian then steamed for $15-20$ minutes in a steaming pot with a temperature of $90-100^{\circ} \mathrm{C}$. Cooked kekian was characterized by a distinctive aroma, changing colour to slightly brown and slightly inflated. The kekian products were then removed from the steaming pot and cooled down.

\section{Determination of the initial formula}

The formula for the kekian is presented in Table 1 .

Table 1. The formula for kekian processing

\begin{tabular}{lrrrr}
\hline \multirow{2}{*}{ Ingredients } & \multicolumn{4}{c}{ Treatments } \\
\cline { 2 - 5 } Minced manyung fish & K0 $(\%)$ & K20 $(\%)$ & K30 $(\%)$ & K40 (\%) \\
Seaweed puree & 67.00 & 47.00 & 37.00 & 27.00 \\
Tapioca flour & 0.00 & 20.00 & 30.00 & 40.00 \\
Sugar & 15.20 & 15.20 & 15.20 & 15.20 \\
Salt & 1.40 & 1.40 & 1.40 & 1.40 \\
Pepper & 1.00 & 1.00 & 1.00 & 1.00 \\
Sesame oil & 0.60 & 0.60 & 0.60 & 0.60 \\
Egg & 0.80 & 0.80 & 0.80 & 0.80 \\
Onion & 6.00 & 6.00 & 6.00 & 6.00 \\
Carrot & 2.00 & 2.00 & 2.00 & 2.00 \\
Ice water & 2.00 & 2.00 & 2.00 & 2.00 \\
\hline Total & 4.00 & 4.00 & 4.00 & 4.00 \\
\hline
\end{tabular}

Note: $\mathrm{K} 0=$ Kekian with $0 \%$ seaweed puree; K20 $=$ Kekian with $20 \%$ seaweed puree; K30 = Kekian with 30\% seaweed puree; $\mathrm{K} 40=$ Kekian with $40 \%$ seaweed puree

\section{Data collection}

The kekians were then subjected to sensory analysis, dietary fiber test, protein content, moisture content, gel strength and Water Holding Capacity (WHC). Sixty untrained panelists analyzed by preference test. The sensory test was applied to appearance, aroma, taste and texture parameters. Each parameter was analyzed using 1-9 distinct scales for: 9 (very like), 8 (really like),

7 (like), 6 (rather like), 5 (neutral), 4 (rather dislike), 3 (dislike), 2 (really dislike) and 1 (very dislike) (BSN, 2006a).

Chemical analysis including dietary fiber using Gravimetric Enzymatic method (AOAC, 2000), moisture content (BSN, 2006b), protein content using the Kjeldahl method (BSN, 2006c), WHC using Centrifugation method (Zayas, 1997) and gel strength measure using texture analysis (BSN, 2009).

\section{Statistical analysis}

The study using completely randomized design with one factor, which is the concentration of E. cottonii puree with four levels as follows $0 \%, 20 \%, 30 \%$ and $40 \%$ and three replications. Sensory data then analyzed by the Kruskal-Wallis test, while data of dietary fiber, moisture content, protein content, WHC and gel strength were analyzed using ANOVA. Further tests were carried out by the Tukey test if there were significant differences $(\alpha<0.05)$.

\section{RESULTS AND DISCUSSION}

\section{Sensory properties}

The result of sensory analysis of kekian showed in Table 2. Based on the results, the addition of seaweed puree to kekian, were significantly affected the characteristics; 
especially in the liking degree of each attribute such as appearance, aroma and texture; while for taste parameters the treatments were not giving significant effects.

Table 2. Sensory properties

\begin{tabular}{lcccc}
\hline \multicolumn{1}{c}{ Parameter } & K0 & K20 & K30 & K40 \\
\hline Appearance & $7.63 \pm 0.49^{\mathrm{a}}$ & $7.67 \pm 0.61^{\mathrm{a}}$ & $7.47 \pm 0.51^{\mathrm{a}}$ & $6.83 \pm 0.65^{\mathrm{b}}$ \\
Aroma & $7.63 \pm 0.49^{\mathrm{a}}$ & $7.60 \pm 0.50^{\mathrm{a}}$ & $6.90 \pm 0.89^{\mathrm{b}}$ & $6.73 \pm 0.83^{\mathrm{b}}$ \\
Taste & $7.90 \pm 0.61^{\mathrm{a}}$ & $7.83 \pm 0.75^{\mathrm{a}}$ & $7.53 \pm 0.51^{\mathrm{a}}$ & $7.63 \pm 0.62^{\mathrm{a}}$ \\
Texture & $7.50 \pm 0.82^{\mathrm{a}}$ & $7.83 \pm 0.79^{\mathrm{a}}$ & $7.37 \pm 0.50^{\mathrm{ab}}$ & $6.83 \pm 0.65^{\mathrm{b}}$ \\
\hline
\end{tabular}

Note: The same letter in the same row showed no significant difference at $\alpha=0.05$

The results of sensory test on the appearance of kekian was ranging from 6.83-7.67. These results showed that panelists preferred the kekian of all treatments. The addition of seaweed puree caused significant differences in the appearance. The shape of kekian which supposed to be tubular with the addition of $40 \%$ seaweed puree were changed into irregularly. The colors of kekian in this study were generally brownishwhite because of the white color of manyung fish meat. The Maillard reaction also influenced the color of the kekian products during the steaming process (Tamanna and Mahmood, 2015).

The aroma in food products came from volatile molecules that were captured by the sense of smell, the nose. The aroma characteristic showed that consumers favored it with an average value ranging from 6.73-7.63. The K30 treatment was able to reduce the distinctive aroma to near neutral. According to Nurjanah et al. (2019), E. cottonii has a specific aroma of seaweed to near neutral.

The taste values of the kekian were ranging between 7.53-7.90. The results showed that panelists favored the taste of the kekian. However, the results were not significantly different among treatments due to the same amount of seasoning used in kekian, which results in a uniform taste. Flavors came from the herbs and spices used. Uniformity in the amount of seasoning would produce similar tastes. Spices in food products were compounds that responsible for certain flavors such as piperine (pepper) and diallyl sulfide (garlic and onion) compounds (Rauf et al., 2015).

The texture was one of the criteria that can influence consumers acceptance. Based on the sensory analysis, the texture of kekian showed average values between 6.83-7.83. These results indicated that the level of preference for each treatment tends to be different. The textures obtained were varied between soft and chewy, but it found to be slowly consumed. This texture is usually found in the high nutritious products which contain carbohydrate, protein and more fiber (Maina, 2018). In this study, the texture of kekians were related to its nutrition contents. High protein products produced a chewy texture; on the other hand, the low protein content produced a softer texture. The higher the addition of seaweed, the softer the texture.

\section{The physicochemical characteristics of kekian}

The chemical composition results are presented in Table 3.

Table 3. The chemical characteristic of kekian

\begin{tabular}{clccrr}
\hline No. & \multicolumn{1}{c}{ Parameter } & K0 & K20 & K30 & \multicolumn{1}{c}{ K40 } \\
\hline 1. & Dietary fiber $(\%)$ & $3.87 \pm 0.31^{\mathrm{d}}$ & $6.03 \pm 0.16^{\mathrm{c}}$ & $7.81 \pm 0.61^{\mathrm{b}}$ & $9.97 \pm 0.21^{\mathrm{a}}$ \\
2. & Moisture content $(\%)$ & $66.34 \pm 1.57^{\mathrm{b}}$ & $69.31 \pm 0.94^{\mathrm{ab}}$ & $71.07 \pm 2.00^{\mathrm{a}}$ & $71.90 \pm 0.70^{\mathrm{a}}$ \\
3. & Protein $(\%)$ & $14.45 \pm 0.50^{\mathrm{a}}$ & $11.49 \pm 1.16^{\mathrm{b}}$ & $9.30 \pm 1.15^{\mathrm{bc}}$ & $8.27 \pm 0.38^{\mathrm{c}}$ \\
\hline
\end{tabular}

Note: The same letter at the same row showed no significant difference $\alpha=0.05$

Table 3 showed that the dietary fiber content of the four treatments were $3.87 \%$; $6.03 \%$; $7.81 \%$ and $9.97 \%$; respectively, which was significantly different. The highest value of dietary fiber was found on K40, while the lowest value was on the $\mathrm{K} 0$. The values of dietary fiber content in the kekian increased along with the addition of seaweed puree. The E. cottonii seaweed, as carrageenan producer, had a high fiber content. The content of dietary fiber in 
E. cottonii seaweed reached $67.5 \%$, consisting $39.47 \%$ water-insoluble fiber and $26.03 \%$ watersoluble fiber (Hermawan et al., 2018).

The K20 had fiber content of $6.03 \%$, which was slightly under the dietary fiber of payus fish meatballs with $20 \%$ seaweed which was $6.05 \%$ (Amaliah et al., 2016). The results of each treatment in this study had a value above $6 \%$ or equal to $6.03 \% ; 7.81 \%$ and $9.97 \%$; respectively. Food was categorized as high-fiber food if the dietary fiber in a food product contains at least $6 \%$ (Noviasari et al., 2017).

The results of dietary fiber in this study were consistent with gel strength. The higher the fiber content, the lower the gel strength. The fiber content influenced the texture because it could inhibit interactions between proteins, so proteins that multiply into $\alpha$-helix form could change. Dietary fiber had larger particles than tissue cells, causing the protein matrix to become less homogeneous and not compact (Pratiwi et al., 2016). Dietary fiber could affect the properties of texture, gel formation, thickness and emulsification (Talukder, 2015).

Water is one component that can affect the texture of food products. The higher moisture content in food, the higher the level of tenderness. Based on the results, the K30 treatment could increase the moisture content of kekian. The K0 treatment (66.34\%) was not significantly different from K20 treatment $(69.31 \%)$, but significantly different from K30 (71.07\%) and K40 (71. 90\%) treatment. The seaweed in this study contained $95.98 \%$ of moisture. The chemical composition of seaweed E. cottonii including moisture $(76.15 \%)$, ash $(5.62 \%)$, protein $(2.32 \%)$, fat $(0.11 \%)$ and carbohydrate (15.8\%) (Maharany et al., 2017).

The moisture content of kekian was ranged from $66.34-71.90 \%$. Based on SNI/Standar Nasional Indonesia 7756-2013, the maximum moisture content in processed fish products is $60 \%$. In this study, the moisture content was higher than the SNI. The results of this study were similar with the payus fish meatball with the seaweed addition Kappaphycus alvarezii 0-20\%, which had moisture content of $68.60-79.97 \%$ (Amaliah et al., 2016). The results of this study were higher because the moisture content in food was influenced by the materials used. The moisture content of seaweed puree was $95.98 \%$, so the moisture content in the kekian products were also increased.
The results of the moisture content in this study were in line with WHC principles; the higher the moisture content, the WHC increased. Carrageenan is a hydrocolloid compound that had a high water-binding ability. Carrageenan holds water in the matrix so that it could increase the concentration of seaweed. The higher the amount of carrageenan, the higher the WHC (Arnyke et al., 2014). Moisture content also affected the texture; the higher the moisture content, the lower the gel strength. The lower the moisture content, the texture would become harder and more compact; on the other hand, low moisture content produced a softer texture. High levels of moisture content ranging from $75-81 \%$ in surimi-based products reduced the gel strength. The lower moisture content would produce more elastic and more robust gel (Wibowo et al., 2015).

Proteins are composed of carbon, hydrogen, oxygen and nitrogen. The result showed that the protein content on $\mathrm{K} 0$ was significantly different from the other treatments. The addition of $20 \%$ and $40 \%$ seaweed puree could reduce the protein value of kekian due to the reduction in fish meat composition and the addition of seaweed puree. Seaweed also contributed to lower the protein content. Seaweed contained $27.8 \%$ water, $5.4 \%$ protein, $33.3 \%$ carbohydrate, $8.6 \%$ fat, $3 \%$ crude fiber and $22.25 \%$ ash (Hidayat et al., 2014).

The average protein contents in this study were $8.27-14.45 \%$ and according to SNI 7756-2013, the minimum protein content in processed fish products was $5 \%$. It means that the four treatments of kekian met the SNI requirements. The results were in line with the protein content of selected beef meatballs with the addition of $40 \%$ seaweed puree of $8.11 \%$ (Princestasari and Amalia, 2015), but lower than of the payus fish meatballs with the addition of $20 \%$ seaweed puree of $12.04 \%$ (Amaliah et al., 2016). The difference in protein levels was influenced by protein content found in fish and due to the processing. The protein in payus fish was $20.42 \%$, whereas manyung fish was 18.2\% (Khamidah et al., 2019; Muharifat et al., 2019).

WHC is the ability of meat to bind water or water that added from the environment such as cutting, heating, grinding and pressing. The results showed that the addition of seaweed increased the WHC value (Table 4). The average WHC was ranged from $34.45-57.65 \%$. The highest WHC value was found on K40 for $57.65 \%$, while the lowest was found on the $\mathrm{K} 0$ for 
$34.45 \%$. The addition of seaweed had a significant effect on WHC. It was because of the presence of carrageenan in E. cottonii which could bind water. The increased seaweed concentration, the higher the carrageenan content and followed by an increase in the WHC as it holds water in the matrix space that was formed (Setyaningrum and Sukesi, 2013).

Table 4. The physical characteristic of kekian

\begin{tabular}{cccccc}
\hline No. & \multicolumn{1}{c}{ Parameter } & K0 & K20 & K30 & K40 \\
\hline 1. & WHC $(\%)$ & $34.45 \pm 0.30^{\mathrm{d}}$ & $39.69 \pm 0.11^{\mathrm{c}}$ & $48.39 \pm 0.47^{\mathrm{b}}$ & $57.65 \pm 0.51^{\mathrm{a}}$ \\
2. & Gel strength (kgf) & $1064.03 \pm 19.97^{\mathrm{a}}$ & $773.82 \pm 18.52^{\mathrm{b}}$ & $652.50 \pm 40.79^{\mathrm{c}}$ & $363.63 \pm 12.84^{\mathrm{d}}$ \\
\hline
\end{tabular}

Note: The same letter at the same row showed no significant difference $\alpha=0.05$

Table 4 showed that increasing seaweed concentration could increase the WHC. The WHC in a product would affect the texture. The higher WHC produced tender texture. Carrageenan in seaweed had a high WHC, resulting in a lower texture value or softer product. The WHC could determine product tenderness. Increasing WHC produced tender texture and vice versa (Wulandari et al., 2016). WHC in this study were in line with moisture value. On the other hand, it was inversely proportional to the protein content where the higher WHC, the lower the protein content. The protein content in seaweed was 5.12\% (Daud, 2013); so, the moisture content increased while the protein decreases.

Gel strength is the ability of a material to break when given the compressive force. The average gel strength values were 363.63-1064.03 kgf. The highest value was found in $\mathrm{K} 0$ and the lowest was in K40. The results showed that the addition of $E$. cottonii tends to reduce the gel strength due to the excess water on the seaweed puree. It indicated by the decreasing value of the gel strength along with the increasing of seaweed puree concentration. The low seaweed concentration produced a chewy texture due to the lack of bounded water, while the addition of high seaweed concentration produced softer texture due to excessive water content. According to Amaliah et al. (2016), the addition of $K$. alvarezii of more than $10 \%$ tends to decrease the payus fish meatball folding test. The seaweed puree contained much water which affected the thickness of the fish meatball. The addition of higher seaweed puree concentration could increase the water content of meatballs and the resulting in lower texture value. Seaweed contributed a considerable amount of water because of its hydrocolloid properties that able to absorb water.

The gel strength of K0, K20 and K30 was categorized as a high gel, while the K40 was categorized as a low gel. Based on the sensory test results, K20 was preferred by panelists with the gel strength of $773.82 \mathrm{kgf}$. The control kekian (K0) had a fairly dense texture, while K20 had a softer texture which was preferred by panelists. Amaliah et al. (2016) showed that the highest value of gel strength was obtained by the addition of $10 \% \mathrm{~K}$. alvarezii seaweed porridge to payus fish meatballs amounting to $802.55 \mathrm{kgf}$. The gel strength was categorized as high if the values were between 601-800 kgf, the medium gel was 401$600 \mathrm{kgf}$ and the low gel was $<400 \mathrm{kgf}$ (Nugroho et al., 2014).

\section{CONCLUSIONS}

It can be concluded that the four treatments were significantly different from the sensory, dietary fiber, moisture, protein content, gel strength and WHC aspects. According to the sensory characteristics, K20 had the best formula that preferred by panelists. Although several parameters in K20, such as appearance, taste and texture, have no significant difference with $\mathrm{K} 30$, it had slightly higher liking scale in aroma parameter for preference test. K20 was rich in fiber due to $6.03 \%$ of dietary fiber, which was lower than K30. The physicochemical characteristics of K20 such as dietary fiber, moisture content, protein content, WHC and gel strength were $6.03 \%, 69.31 \%, 11.49 \%, 39.69 \%$ and $773.82 \mathrm{kgf}$; respectively.

\section{REFERENCES}

Amaliah, S., Munandar, A., \& Haryati, S. (2016). Influence of incresment Kappaphycus alvarezi porridge toward Elops hawaiensis meatballs characteristic. Jurnal Perikanan dan Kelautan, 6(1), 40-50. http://dx.doi.org/10.33512/jpk. v6i1.1051

AOAC. (2000). Official methods of analysis, 
association of analytical chemists. 15th ed. https://doi.org/10.1007/978-3-642-31241-0

Arnyke, E. V., Rosyidi, D., \& Radiati, L. E. (2014). Peningkatan potensi pangan fungsional naget daging kelinci dengan substitusi wheat bran, pollard dan rumput laut. Jurnal Ilmu-Ilmu Peternakan, 24(1), 56-71. Retrieved from https://jiip.ub.ac.id/index.php/ jiip/issue/view/31

Badan Standarisasi Nasional (BSN). (2006a). Standar Nasional Indonesia (SNI) 01-23462006 Petunjuk Pengujian Organoleptik dan Atau Sensori. Jakarta. Retrieved from https://drive.google.com/file/d/1Oone5rOJUo cXiM5UlcvoWgnDr18e4tYk/view

Badan Standarisasi Nasional (BSN). (2006b). Standar Nasional Indonesia (SNI) 01-2354.22006 Cara Uji Kimia - Bagian 2: Penentuan Kadar Air pada Produk Perikanan. Jakarta. Retrieved from https://kupdf.net/download/sni -01-2354-2-2006-penentuan-kadar-air-produk -perikanan_58d0f0f6dc0d60c016c34640_pdf

Badan Standarisasi Nasional (BSN). (2006c). Standar Nasional Indonesia (SNI) 01-2354.42006 Cara Uji Kimia - Bagian 4: Penentuan Kadar Protein dengan Metode Total Nitrogen pada Produk Perikanan. Jakarta. Retrieved from https://fdokumen.com/document/sni-0123544-2006-protein-metode.html

Badan Standarisasi Nasional (BSN). (2009). Standar Nasional Indonesia (SNI) No. 2372.6:2009 Cara Uji Fisika-Bagian 6: Pasta pada Produk Perikanan. Jakarta. Retrieved from https://www.scribd.com/document/3554 13733/SNI-surimi-2013-pdf

Battacharyya, D., Babgohari, M. Z., Rathor, P., \& Prithiviraj, B. (2015). Seaweed extracts as biostimulants in horticulture. Scientia Horticulturae, 196, 39-48. https://doi.org/ 10.1016/j.scienta.2015.09.012

Bouga, M., \& Combet, E. (2015). Emergence of seaweed and seaweed-containing foods in the UK: Focus on labeling, iodine content, toxicity and nutrition. Foods, 4(4), 240-253. https:// doi.org/https://doi.org/10.3390/foods4020240

Das, A. K., Nanda, P. K., Madane, P., Biswas, S., Das, A., Zhang, W., \& Lorenzo, J. M. (2020). A comprehensive review on antioxidant dietary fibre enriched meat-based functional foods. Trends in Food Science and Technology, 99, 323-336. https://doi.org/ 10.1016/j.tifs.2020.03.010

Daud, R. (2013). Pengaruh masa tanam terhadap kualitas rumput laut, Kappaphycus alvarezii. Media Akuakultur, 8(2), 135-138. https://doi. org/10.15578/ma.8.2.2013.135-138

Febriana, T., Karimuna, L., \& Asyik, N. (2017). The effect of formulation of carrot (Daucus carota L.) and seaweed (Eucheuma cottonii) on the organoleptic properties and nutritional values of tofu nugget. Jurnal Sains dan Teknologi Pangan, 2(2), 405-412. http://ojs. uho.ac.id/index.php/jstp/article/download/260 $5 / 1943$

Firdaus, M., Yahya, Nugraha, G. R. H., \& Utari, D. D. (2017). Fortification of seaweed (Eucheuma cottonii) flour on nutrition, iodine, and glycemic index of pasta. IOP Conference Series: Earth and Environmental Science, 89(1), 1-6. https://doi.org/10.1088/1755-1315 /89/1/012011

Fontes-Candia, C., Ström, A., Lopez-Sanchez, P., López-Rubio, A., \& Martínez-Sanz, M. (2020). Rheological and structural characterization of carrageenan emulsion gels. Algal Research, 47, 101873. https://doi.org/ 10.1016/j.algal.2020.101873

Hadibroto, C. (2011). Masakan Tionghoa. Jakarta: PT Gramedia Pustaka Utama.

Halimah, S. N., Suryani, R. A., Wijayanti, S. W., Pangestu, R. A., Deni, G. D., \& Romadhon. (2016). Fortification seaweed noodles [Euchema cottonii (Weber-van Bosse, 1913)] with nano-calcium from bone catfish [Clarias batrachus (Linnaeus, 1758)]. Aquatic Procedia, 7, 221-225. https://doi.org/10.1016/ j.aqpro.2016.07.030

Handayani, R., \& Aminah, S. (2011). Dietary fiber and organoleptic value on cake seaweed (Eucheuma cottonii) from the seaweed substitution. Jurnal Pangan Dan Gizi, 2(3), 67-74. https://doi.org/10.26714/jpg.2.1.2011.

Hermalena, L., \& Salihat, R. A. (2018). Analisis senyawa kimia pada bakso ikan tetelan merah tuna dengan penambahan jamur tiram putih (Pleurotus ostreatus) dengan metode GC-MS. Menara Ilmu, 12(79), 124-127. Retrieved from https://jurnal.umsb.ac.id/index.php/mena 
railmu/article/view/520

Hermawan, D., Warkoyo, W., Jasmine, C., \& Pakpahan, O. P. (2018). Study of proportions seaweed Eucheuma cottonii L. and cooking time on quality of functional of seaweed dodol. Omni-Akuatika, 14(2), 37-42. https://doi.org/ 10.20884/1.OA.2018.14.2.540

Hernández-Herrera, R. M., Santacruz-Ruvalcaba, F., Briceño-Domínguez, D. R., Di FilippoHerrera, D. A., \& Hernández-Carmona, G. (2018). Seaweed as potential plant growth stimulants for agriculture in Mexico. Hidrobiologica, 28(1), 129-140. https://doi .org/10.24275/uam/izt/dcbs/hidro/2018v28n1/ hernandezc

Hidayat, N., Ilza, M., \& Syahrul. (2014). A study on seaweed (Eucheuma cottonii) application as additional material in catfish (Pangasius hypopthalmus) kamaboko. Jurnal Perikanan Dan Kelautan, 19(2), 33-41. Retrieved from https://media.neliti.com/media/publications/2 96033-kajian-penggunaan-rumput-laut-euche uma-c-029b96d9.pdf

Ismawati, R., Romadhoni, I. F., Nurul, Q. T., \& Ratna, S. T. (2019). Storability of seaweed jelly candy based on chemical, physical and microbiology characteristics. IOP Conference Series: Earth and Environmental Science, 347(1), 1-10. https://doi.org/10.1088/1755$1315 / 347 / 1 / 012021$

Istiqomah, A., \& Rustanti, N. (2015). Indeks glikemik, beban glikemik, kadar protein, serat, dan tingkat kesukaan kue kering tepung garut dengan substitusi tepung kacang merah. Journal of Nutrition College, 4(2), 620-627. https://doi.org/10.14710/jnc.v4i4.10171

Kaiang, D. B., Montolalu, L. A., \& Montolalu, R. I. (2016). Kajian mutu ikan tongkol (Euthynus affinis) asap utuh yang dikemas vakum dan non vakum selama 2 hari penyimpanan pada suhu kamar. Media Teknologi Hasil Perikanan, 4(2), 75-84. https://doi.org/ 10.35800/mthp.4.2.2016.13034

Khamidah, S., Swastawati, F., \& Romadhon. (2019). Effects of different dipping duration into durian skin liquid smoke on the quality of catfish (Arius thalassinus) smoked. Jurnal Ilmu Dan Teknologi Perikanan, 1(1), 21-29. Retrieved from https://ejournal2.undip.ac.id/ index.php/jitpi/article/download/5241/2824

Khoirunisa, H., Nasrullah, N., \& Maryusman, T. (2019). Karakteristik sensoris dan kandungan serat biskuit dari jantung pisang (Musa paradisiaca) sebagai makanan selingan anak obesitas. Jurnal Teknologi Pangan dan Kesehatan, 1(2), 93-100. Retrieved from https://www.researchgate.net/deref/http $\% 3 \mathrm{~A}$ $\% 2 \mathrm{~F} \% 2 \mathrm{Fdx}$.doi.org\%2F10.36441\%2Fjtepake s.v1i2.192

Kolade, O. Y. (2015). Assessment of nutritional composition of commerically sold fish based ready to eat food (fish roll) in some parts of Lagos Metropolis, South West Nigeria. The Bioscientist, 3(1), 31-38. Retrieved from https://bioscientistjournal.com/index.php/The _Bioscientist/issue/view/5

Li, Y. O., \& Komarek, A. R. (2017). Dietary fibre basics: Health, nutrition, analysis, and applications. Food Quality and Safety, 1(1), 47-59. https://doi.org/10.1093/fqs/fyx007

Maharany, F., Nurjanah, Suwandi, R., Anwar, E., \& Hidayat, T. (2017). Bioactive compounds of seaweed Padina australis and Eucheuma cottonii as sunscreen raw materials. JPHPI, 20(1), 10-17. https://doi.org/10.17844/jphpi. 2017.20.1.10

Maina, J. W. (2018). Analysis of the factors that determine food acceptability. The Pharma Innovation Journal, 7(5), 253-257. Retrieved from www.thepharmajournal.com

Muharifat, I. K., Haryati, S., \& Munandar, A. (2019). Characteristic of "Bontot" combined of Hawaiian Ladyfish (Elops hawaiiensis) meat and Tarpon fish (Megalops cyprinoides). JPHPI, 22(3), 476-482. Retrieved from https://www.researchgate.net/publication/338 767777_Characteristic_of_Bontot_Combined _of_Hawaiian_Ladyfish_Elops_hawaiiensis_ Meat_and_Tarpon_Fish_Megalops_cyprinoid es/fulltext/5e2992db92851c3aadd39bd9/Char acteristic-of-Bontot-Combined-of-HawaiianLadyfish-Elops-hawaiiensis-Meat-and-Tarpon -Fish-Megalops-cyprinoides.pdf

Mustafida, H., Darmanto, Y., \& Anggo, A. D. (2019). The effect of various types of skin fish gelatine to fish kekian characteristics from Tilapia (Oreochromis niloticus). SAINTEK PERIKANAN: Indonesian Journal of 
Fisheries Science and Technology, 15(1), 1925. https://doi.org/10.14710/ijfst.15.1.19-25

Nabti, E., Jha, B., \& Hartmann, A. (2016). Impact of seaweeds on agricultural crop production as biofertilizer. International Journal of Environmental Science and Technology, 14(5), 1119-1134. https://doi.org/10.1007/ s13762-016-1202-1

Nur Fatin Nazurah, R., \& Nur Hanani, Z. A. (2017). Physicochemical characterization of kappa-carrageenan (Euchema cottoni) based films incorporated with various plant oils. Carbohydrate Polymers, 157, 1479-1487. https://doi.org/10.1016/j.carbpol.2016.11.026

Noviasari, S., Kusnandar, F., Setiyono, A., \& Budijanto, S. (2017). Physical, chemical, and sensory characteristics of rice analogue from non rice ingredients. Pangan, 26(1), 1-12. Retrieved from https://www.researchgate.net/ publication/321299989_Physical_Chemical_a nd_Sensory_Characteristics_of_Rice_Analog ue_from_Non_Rice_Ingredients

Nugroho, A., Swastawati, F., \& Anggo, A. D. (2014). The effect of flour and frying time to the quality of Spanish Mackerel (Scomberomorus sp.) fish drum stick. Jurnal Pengolahan dan Bioteknologi Hasil Perikanan, 3(4), 140-149. Retrieved from https://media.neliti.com/media/publications/1 25036-ID-none.pdf

Nurjanah, Fauziyah, S., \& Abdullah, A. (2019). Characteristic of seaweed porridge Eucheuma cottonii and Turbinaria conoides as raw peel off mask. Jurnal Pengolahan Hasil Perikanan Indonesia, 22(3), 391-402. Retrieved from https://www.jurnal.ipb.ac.id/index.php/jphpi/a rticle/view/27893/0

Pati, M. P., Sharma, S. D, Nayak, L., \& Panda, C. R. (2016). Uses of seaweed and its application to human welfare: A review. International Journal of Pharmacy and Pharmaceutical Sciences, 8(10), 12-20. https://doi.org/ 10.22159/ijpps.2016v8i10.12740

Pereira, L. (2018). Seaweeds as source of bioactive substances and skin care therapy-Cosmeceuticals, algotheraphy, and thalassotherapy. Cosmetics, 5(4), 68. https:// doi.org/10.3390/cosmetics5040068

Pratiwi, T., Affandi, D. R., \& Manuhara, G. J.
(2016). The application of lesser yam flour (Dioscorea esculenta) as wheat flour substitution in tuna fish (Euthynnus affinis) nugget filler. Jurnal Teknologi Hasil Pertanian, 9(1), 34-50. Retrieved from https://jurnal.uns.ac.id/ilmupangan/article/do wnload/12852/10916

Princestasari, L. D., \& Amalia, L. (2015). Formulation of Gracilaria sp. seaweed in making high fiber and iodine meatball. Jurnal Gizi Pangan, 10(3), 185-196. https://doi. org/10.25182/jgp.2015.10.3.\%25p

Priono, B. (2016). Budidaya rumput laut dalam upaya peningkatan industrialisasi perikanan. Media Akuakultur, 8(1), 1-8. https://doi.org/ 10.15578/ma.8.1.2013.1-8

Rauf, N. H., Sulistijowati, R. S., \& Harmain, R. M. (2015). Mutu organoleptik sosis ikan lele yang disubtitusi dengan rumput laut. Jurnal Ilmiah Perikanan dan Kelautan, 3(3), 125-129. Retrieved from http://ejurnal.ung. ac.id/index.php/nike/article/viewFile/1323/10 69

Satriani, Sukainah, A., \& Mustarin, A. (2018). Analysis physico-chemical of ice cream with additions of sweet corn (Zea mays L. Saccharata) and seaweed (Eucheuma cottonii). Jurnal Pendidikan Teknologi Pertanian, 4, 105-124. https://doi.org/10.26858/jptp.v1i0.6 237

Septiana, P., Nugroho, F. A., \& Wilujeng, C. S. (2018). Junk food and fiber consumption among overweight and obese young women living in boarding house. Jurnal Kedokteran Brawijaya, 30(1), 61-67. https://doi.org/ 10.21776/ub.jkb.2018.030.01.11

Setyaningrum, A., \& Sukesi. (2013). Preparasi penentuan $\mathrm{Ca}, \mathrm{Na}$, dan $\mathrm{K}$ dalam nugget ayamrumput laut (Eucheuma cottonii). Jurnal Sains dan Seni Pomits, 2(1), 1-4. Retrieved from http://ejurnal.its.ac.id/index.php/sains_seni/art icle/view/4308

Shanti, K. M., Andarini, S., Mutiyani, M., Wirawan, N. N., \& Rahmawati, W. (2017). Asupan serat dan IMT wanita usia subur Suku Madura di Kota Malang. Indonesian Journal of Human Nutrition, 4(1), 1-11. https://doi. org/10.21776/ub.ijhn.2016.003.Suplemen.5

Talukder, S. (2015). Effect of dietary fiber on 
properties and acceptance of meat products: A review. Critical Reviews in Food Science and Nutrition, 55(7), 1005-1011. https://doi.org/ 10.1080/10408398.2012.682230

Tamanna, N., \& Mahmood, N. (2015). Food processing and maillard reaction products: effect on human health and nutrition. International Journal of Food Science, 1-6. https://doi.org/10.1155/2015/526762

Wibowo, A. (2019). Rumput laut, komoditas penting yang belum dioptimalkan. KKP | Kementerian Kelautan dan Perikanan Retrieved from https://kkp.go.id/djpdspkp/bbp 2hp/artikel/14127-rumput-laut-komoditas-pen ting-yang-belum-dioptimalkan

Wibowo, T., Darmanto, Y., \& Amalia, U. (2015).
The characteristics of "Kekian" from threadfin breams (Nemipterus nematophorus) surimi with different addition of fish meat. Jurnal Pengolahan dan Bioteknologi Hasil Perikanan, 4(2), 17-24. Retrieved from https://ejournal3.undip.ac.id/index.php/jpbhp/ article/view/8656

Wulandari, E., Suryaningsih, L., Pratama, A., Putra, D. S., \& Runtini, N. (2016). Effect of tomatos paste to physicochemical and sensory characteristics chicken nuggets. Jurnal Ilmu Ternak, 16(2), 95-99. Retrieved from https:// core.ac.uk/download/pdf/291489920.pdf

Zayas J. F. (1997) Water holding capacity of proteins. In: Functionality of Proteins in Food. Springer, Berlin, Heidelberg. https:// doi.org/10.1007/978-3-642-59116-7_3 